\title{
How Can Cancer-Associated Anemia Be Moderated with Nutritional Factors and How Do Beta Vulgaris L. Ssp. Esculenta Var. Rubra Modify the Transmethylation Reaction in Erythrocytes in Cancerous Patients?
}

\author{
Anna Blázovics ${ }^{1}$ et al. ${ }^{*}$ \\ ${ }^{1}$ Department of Pharmacognosy, and II. Department \\ of Medicine, Semmelweis University, Budapest \\ Hungary
}

\section{Introduction}

Genetic predisposition, unhealthy dietary or life habits and heavy social circumstances could result in the changes of redox homeostasis, which is very important for the equilibrium between tissue regeneration and apoptosis. When the balance is disturbed, cancer and/or necrosis may develop (Powis et al., 1997). Moderate dietary habits with natural bioactive agents, antioxidants, methyl donor molecules and metal elements can help restore the normal function of the organism, although the immoderate consumption of nutritive components is contraindicated. Long term antioxidant and/or antioxidant-related treatments as well as metal element owerflow can modify redox-homeostasis because these alimentary components effect signal transduction routes and compensatory effects of altered tissues can be observed (Vanherweghem et al., 1993, Blázovics et al., 2007a,b, Blázovics et al., 2008).

Epidemiological, experimental and clinical investigations have shown that food supplements are not effective in cancer therapy because of inappropriate usage in cases of people suffering from cancers with low vitamin and trace element levels. Significant changes of total scavenger capacity, metal element concentrations, bounded HCHO and

\footnotetext{
"Péter Nyirády², Imre Romics², Miklós Szúcs², András Horváth², Ágnes Szilvás³, Edit Székely¹, Klára Szentmihályi ${ }^{4}$, Gabriella Bekő ${ }^{5}$ and Éva Sárdi ${ }^{6}$

${ }^{1}$ Department of Pharmacognosy, and II. Department of Medicine, Semmelweis University, Budapest, 2Department of Urology, Semmelweis University,

3Saint John Hospital, Budapest,

4Institute of Materials and Environmental Chemistry, CRC, Hungarian Academy of Sciences, Budapest, ${ }^{5}$ Central Laboratory Pest, Semmelweis University,

${ }^{6}$ Corvinus University, Budapest
} 
protoporphyrin as well as Zn-protoporphyrin concentrations in erythrocytes can be observed in cancerous processes, which are very important in cancer-associated anemia (Blázovics et al., 2008).

Red blood cells do not get enough oxygen to all parts of the body especially in cancerrelated anemia, such as cancer in bone marrow directly or in metastasis, as well as in cisplatin or carboplatin chemotherapy, which lower the erythropoietin production in the kidneys and in radiation therapy caused anemia. It is especially significant if the level of the transmethylation ability is too low in the organism. Alterations in DNA methylation play an important role in neoplasia (Baylin, et al. 1997, Calvisi et al., 2007). DNA hypomethylation leads to elevated mutation rates. (Chen et al. 1998). The most studied mechanisms by epigenetics are DNA and histone methylation and the stable and reversible alterations in the genome that affect gene expression and genome function. The nature and role of the mechanisms of promoter hypermethylation during carcinogenesis were studied worldwide, however the mechanism behind one of the earliest epigenetic observations in cancer nowadays, genome-wide hypomethylation, still remains unclear (Wild, and Flanagan 2010)

Tumor hypermethylation predicts a poor prognosis in patients with earlier stages of prostate cancer, and is commonly found in the plasma DNA of patients with castrationresistant prostate cancer (Rosenbaum et al., 2005, Bastian et al. 2009). Low transmethylation ability can be observed in the erythrocyte in different tumors and in different stages (Blázovics et al., 2008, Nyirády et al., 2010). Hypomethylation seems to be a condition of the system, which can be improved with methyl donating molecules from food ingredients, such as different $\mathrm{N}-$, S- and $\mathrm{O}$ - methylated compounds.

\section{Natural therapy and cancer-related anemia}

In spite of an enormous effort and many new excellent experimental data, which come to light in cancer research, cancer therapy is not solved satisfactorily. Several target points are for inhibiting cancerous processes and molecules are developed to modify signal transduction pathways aimed for a better way of using tailored cancer treatment, although the chance of definitive recovery is very different in the various tumors and only half of circa 200 tumor types can be cured nowadays (Blázovics 2011). Therefore new therapeutic solutions are necessary as well as looking for new food ingredients to moderate several problems, such as cancer-related anemia, which improves the erythrocyte function of bone metastatic prostate cancer cases.

It is an endeavor to show attempts of natural therapy with small molecules for inhibiting cancer growth and spreading on the basis of researches. The effectiveness of medicinal therapy can be increased if the therapy is planned for each patient therefore this chapter wants to deal with the importance of the role of transmethylation ability and the question of modification of redox-homeostasis by alimentary supporting therapy.

\subsection{Transmethylation processes}

Bioactive molecule, the small genotoxic and carcinogen formaldehyde is in connection with the redox homeostasis. This molecule plays an important role with free radicals in the biological system (Lichszteld and Kruk 1977, Nieva and Wentworth 2004). Since 
endogenous transmethylation processes occur via $\mathrm{HCHO}$, this molecule can be considered as an ancient and basic compound of life systems. HCHO can be found in animal tissues in specially-bounded, mainly hydroxymethyl forms. Endogenous $\mathrm{HCHO}$ is produced partly by the enzymatic demethylation of different N-, S-, and O- methylated compounds (Huszti et al., 1986, Sárdi et al., 2005, Kovács-Nagy et al., 2009).

S-adenosylmethionine is an important methyl donor in several biological transmethylation reactions such as in the duplication of virus. The product Sadenosylhomocysteine inhibits the transmethylation process because this molecule is hydrolysed to adenosine and L-homocysteine by the action of S-adenosylhomocysteine hydrolase. The accumulation of homocysteine leads to increased cellular oxidative stress (Gersbeck et al., 1989, Stead et al., 2006).

DNA methylation typically occurs at cytosine-phosphate-guanine site. In this process, methylation results in the conversion of the cytosine to 5-methylcytosine. This reaction is catalysed by DNA methyltransferase. The methylation stage of this region can have a major impact on gene (Watson et al., 2003).

Some quaternary ammonium compounds, such as $\mathrm{N}^{\varepsilon}$-trimethyl-L-lysine, choline and betaine, are potential $\mathrm{HCHO}$ generators as well. Data show the important role of $\mathrm{HCHO}$ in proliferative as well as in apoptotic processes. Transmethylation ability is lowered in tumorous processes (Blázovics et al., 2008, Nyirády et al., 2010).

It is also verified, that the arginine (38), methionine (65) and the lysine (72) near the methionine (80) are methylated and coordinated towards the central iron of heme (Stryeer 1988). During moderate transmethylation ability, free protoporphyrin can be found near the Zn-protoporphyrin in the erythrocyte in different cancers and it has pro- and antioxidant forms depending on concentrations. Protoporphyrin concentration is low in cancerous patients, but in metastasis its concentration is significantly high. Oxidized hemoglobin, $\mathrm{HbA1c}$ correlates significantly with free radical reactions and with decreased antioxidant status of erythrocytes (Blázovics et al., 2008).

In earlier study, significant changes could be observed in erythrocyte function in patients suffering from colon cancer as well as in metastatic prostate cancer. The erythrocyte mobilized formaldehyde was significantly lower in adult colectomysed patients with no metastasis than in controls. Simultaneously protoporphyrin concentration was low in patients without metastasis, when the diagnosis was Dukes $C$ before operation. HbA1c level correlated significantly with the induced free radical level and decreased antioxidant status of erythrocytes (Blázovics et al., 2008, 2011).

\subsection{Redox homeostasis}

Redox homeostasis can be considered as the cumulative action of free radicals and antioxidant defenses, providing a suitable condition for life. Oxidative stress is a key modulator, which modifies the ligand-receptor interactions extracellularly and intracellularly, and influences gene expression. Free radicals can act as secondary messengers in several transduction pathways, and take part in the activation of chemotactic cytokines and surface adhesion molecules etc. (Abate et al., 1990, Meyer et al., 1993, Polya et al., 2002).

Oxidative stress can induce stress response genes, and moderate oxidative stress by down regulating the gene expression of several genes. DNA synthesis, selective gene expression, 
enzyme activation and modification of cell proliferation are involved in redoxy signal mechanisms. Moderate free radical production can modify the function of kinases or directly activate the transcription factors, thereby also influencing the gene regulation in the nucleus (Delerive et al., 2000, Kong et al., 2000).

The "antioxidant" concept has meaning only in defense against free radicals for a long period. Its importance is not doubtful in the therapy of diseases in which free radicals are also involved.

Antioxidant consumption is sine qua non for a healthy way of life, but the concentration range is large and dependent on an individual genetic background. Moderate nutritional customs with natural scavengers or antioxidants can help to restore the normal function of tissues and organs, but the immoderate consumption of vitamins and other bioactive agents is contraindicated. The balance between oxidative stress and antioxidant defense is overturned in diseases (Blázovics et al., 1999, Szilvási et al., 1999, Hagymási et al., 2001). Moderate oxidative stress is important in signal transduction pathways and essential for proliferation and apoptosis. The antioxidant overflow as well as oxidative stress mean serious problems. "Janus face" antioxidants can stop protein phosphorylation and the inhibition of activation of transcription factors. They can also therefore stop cell proliferation and injure the adaptation mechanisms against oxidative stress. The direct roles of these antioxidants in original forms are doubtful in transduction therapy (Azzi et al., 2004, Griffiths and Lunec 2001).

Several food-related bioactive agents are important in cancer prevention as well. Metals are also important both in free radical formation and in antioxidant defense in signal transduction.

Four simple redox measurements, H-donating ability, reducing-power property, free SHgroup and stimulated chemiluminescent intensity of plasma and erythrocytes can be applied to evaluate the redox homeostasis in several diseases and different treatments compared to the control values. The calculation of total scavenger capacity can be necessary to measure the tissue relative chemiluminescent light. Normal range of healthy peoples is no more 70 RLU\%, $80 \pm 10 \%$ RLU\% is the chemiluminescent intensity of erythrocytes in different diseases, e.g. in the severe IBD, where the range is $100 \pm 10 \%$, and the range between 100 and 150 RLU\% means increased risk for tumors (precancerous stadium and after tumor resection) and $>150$ RLU\% marks the non treated tumors. Very low chemiluminescent intensity - significantly lower than that of healthy control patients - could be observed in metastatic cancerous patients, some weeks before death because of extra high protoporphyrin concentration in the erythrocyte.

Chemiluminescence methods are suitable to differentiate the grade of diseases (Blázovics et al., 1999.) and difference between genders e.g in alcoholic liver diseases (Hagymási et al., 2001), but in both type of IBD and colon cancer gender difference was not observed (Szilvás et al., 1999).

The measured data are in significant correlation with each other and the changes of activity of erythrocyte superoxide dismutase and glutathione peroxidase as well as concentrations of plasma reducing power and $\mathrm{H}$-donating ability. Consequently, erythrocyte total scavenger capacity (inverse of chemiluminescent intensity) is a good predictive factor for neoplasia in early stage (Blázovics et al., 2008). (Figure 1.) 


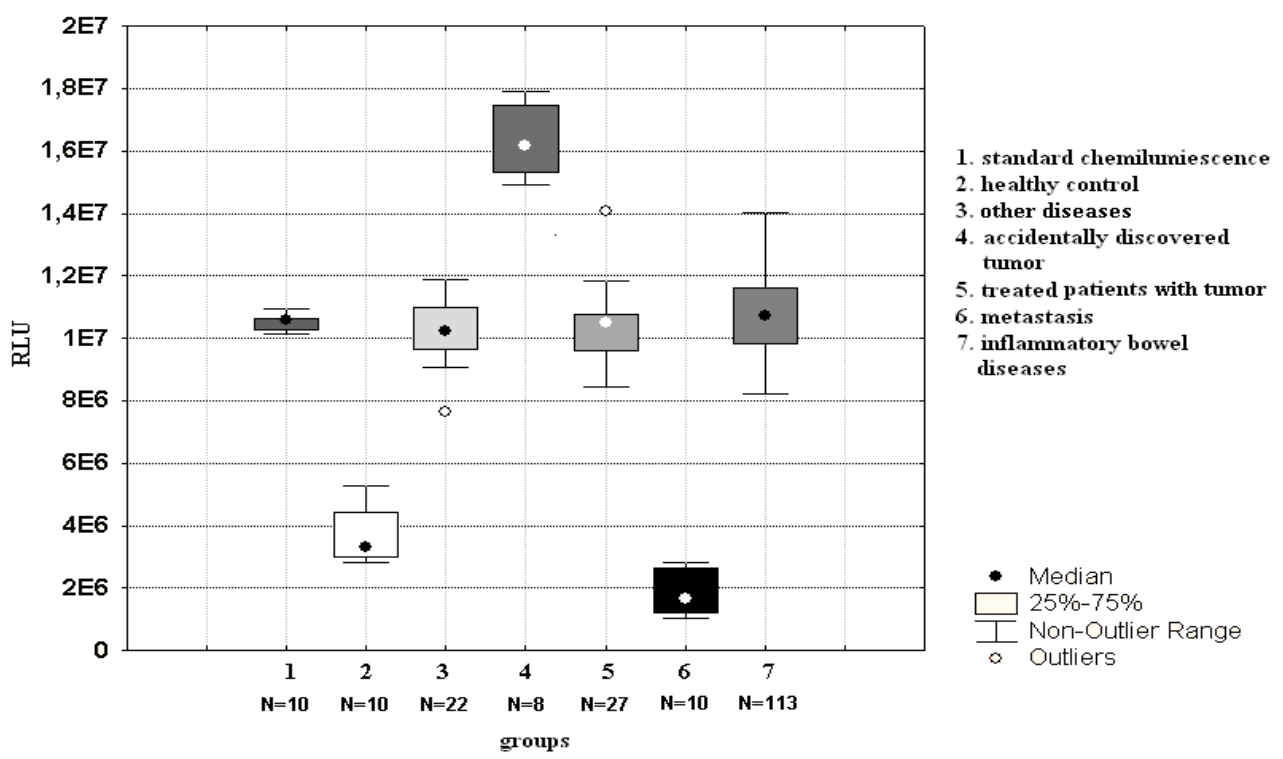

Fig. 1. Chemiluminescent intensity in early state of tumor and metastasis

A significantly higher chemiluminescent intensity of erythrocytes was detected in newly observed tumors. When the patients were operated and treated with chemotherapy and/or irradiation therapy, the erythrocyte chemiluminescence was not altered from that of IBD patients. In severe metastatic stages, before death, the chemiluminescence of erythrocytes was very low, significantly lower than in healthy controls. Plasma chemiluminescence studies rather show only momentary improvement in the course of the therapy of IBD or tumors (Blázovics 2006).

\subsection{Nutritional factors in tumor}

Besides, genetical disposition it was above mentioned, that lifestyle and nutrition with vitamins, polyphenols, flavonoids and quaterner ammonium derivatives play a decisive role in human health care and inhibit the occurrence of many diseases. It is a proven fact that antioxidants have an important role in preventing cancer and improve redox homeostasis (Lugasi and Hóvári 2002, Polya et al., 2002).

Lack of alimentary factors such as iron, vitamin B12, and folic acid, the formation and function of red blood cells is inhibited. These components are available naturally in several vegetables and food items, therefore eating foods with high iron content, such as red meats, dried beans or fruits, almonds, broccoli, and enriched breads and cereals or high folic acid, such as cereals, green leafy vegetables, asparagus, broccoli, spinach, and lima beans can help (Kuramoto et al., 1996).

Bioactive agent as well as metal element-rich vegetables are important in the food chain and play a decisive role in human health care. Table beet is a particularly important vegetable 
from this supporting alimentary point of view. Table beet is a vegetable that is rich in content of folic acid, iron, betaine, natural coloring agents, polyphenols, metal elements, etc. (Takács-Hájos 1999, Blázovics et al ., 2007, Sárdi et al., 2009).

A healthy system needs antioxidant and metal element supplementation and can tolerate occasional overflow between wide boundaries. Besides this, redox homeostasis and element homeostasis do not change. However, the reactions of sick organisms - e.g. the Fe accumulating porphyria cutanea tarda and haemochromatosis or $\mathrm{Cu}$ accumulating Wilson disease as well as the iron-deficiency anemia and the malnutrition of inflammatory bowel diseases - can be different and that is why everybody must be cautious when recommending table beet root supplements. It can be supposed, that the extreme consumption of table beet root can cause several disturbances among others not only in healthy people but in patients suffering from metal accumulating diseases, although moderate consumption may be beneficial in metal-deficiency diseases (Blázovics et al., 2007b).

\subsection{Table beet}

Beta vulgaris L. ssp. esculenta Gurke var. rubra belongs to the Chenopodiaceae family and it is in relationship with Beta vulgaris L. provar. altissima, Beta vulgaris L. convar. crassa provar. crassa and Beta vulgaris L. convar. cicla. An ancient form of these species is the wild form of Beta vulgaris L. var. maritime (Takács-Hájos 1999).

The root of the plant Beta vulgaris L. ssp. esculenta var. rubra is commonly called table beet and has been used for centuries as a traditional and popular food in many national cuisines. The Greek Hypocrates, the Roman, but Greek-born Galenus, the Arabian Avicenna, and the Swiss Paracelsus applied table beet in several gastrointestinal diseases, fevers, anemia, wound-healing etc. Nowadays table beet is also an important component of popular medicine (Frank et al., 2005, Pedreno and Escribano 2000).

The applying of table beet in several diseases can be bordered because the natural colored pigment contents of this vegetable are important food coloring matters, which substitute E123 coloring matter in different creams, substituting soya foods, sweets, gelatin deserts, yogurts, ice- creams, dressings and meats etc. (Takács-Hájos 1999).

Beneficial medical effects are due to bioactive components, such as betaine, betanins, betaxanthins, vulgaxanthine, flavonoids, polyphenols, vitamins (thiamine, riboflavine, piridoxine, ascorbic acid, biotin and folic acid) as well as soluble fibre, pectin and different metal elements (e.g. $\mathrm{Al}, \mathrm{B}, \mathrm{Ba}, \mathrm{Ca}, \mathrm{Cu}, \mathrm{Fe}, \mathrm{K}, \mathrm{Mg}, \mathrm{Mn}, \mathrm{Na}, \mathrm{Zn}$ ), which act on various physiological routes (Wang and Goldman 1996, Rice-Evans et al., 1997, Bobek et al., 2000, Kanner et al., 2001).

The coloring matters in table beet are betalains, as red betacyanins and yellow betaxanthins, and they can be used for human nutrition and prevention of numerous diseases, for example skin and lung cancers (Stintzing and Carle 2004, Schwartz et al., 1983, Frank et al., 2005, Boyd et al., 1982, Kapadia et al., 1996, Kapadia et al. 2003).

According to newer researches, these colored pigments have antioxidant activity and play an important role in the development of antioxidant status in the human organism (Cai et al., 2001, Kanner et al., 2001, Pedreno and Escribano 2000., Wettasinghe et al., 2002, Zakharova and Petrova 1998).

Table beets are mainly characterized by the non high-concentration of sucrose. Glucose and fructose can also be found in the samples but their concentrations are significantly low. With 
regard to glucose quantity, $51 \%$ of the varieties were below $0.2 \mathrm{mg} / \mathrm{g}, 30 \%$ of them belong to the $0.2-0.4 \mathrm{mg} / \mathrm{g}$ domain and $19 \%$ were characterized by a glucose content above $0.4 \mathrm{mg} / \mathrm{g}$. $52.7 \%$ of the varieties were in the $10-15 \mathrm{mg} / \mathrm{g}$ domain, $33 \%$ were between $15-20 \mathrm{mg} / \mathrm{g}$, while $14.3 \%$ contained more that $21 \mathrm{mg} / \mathrm{g}$ sucrose.

Among the quarternary ammonium compounds, which have human health significance due to their biological activity, a high concentration of betaine can be found.

In earlier examinations, among the quaternary ammonium compounds, in the table beet samples betaine was found in the highest concentration, carnitine was also detectable but in low concentration (the value was not measurable) and other quaternary ammonium compounds were not detectable. $28.5 \%$ of the varieties fall under the $0.6 \mathrm{mg} / \mathrm{g}$ level, another $28.5 \%$ are above the $0.8 \mathrm{mg} / \mathrm{g}$ level and $43 \%$ can be characterized by a betaine concentration of $0.6-0.8 \mathrm{mg} / \mathrm{g}$ per fresh mass. Betaine was found in significantly higher concentration in the lyophilized samples. Fresh samples contained betaine in a concentration of 0.35-1.3 $\mathrm{mg} / \mathrm{g}$, while the concentration of lyophilized ones was between $10.3-18.0 \mathrm{mg} / \mathrm{g}$ of dry mass. On the basis of the total phenol concentration of table beet squeezed juice, $23.8 \%$ of the compared varieties are under the level of $0.6-0.8 \mathrm{mg} / \mathrm{ml}$ in the fresh samples, one-third are $0.80-1.0 \mathrm{mg} / \mathrm{ml}$, another one-third are $1.0-1.20 \mathrm{mg} / \mathrm{ml}$ and the phenol concentration of $9.5 \%$ of the varieties is between 1.20-2.0 mg/ml (Sárdi et al., 2009). On the basis of the comparison of studied variants, those with a higher concentration of betanine contained a higher amount of phenol as well. The value of betanine is $0.40-1.1 \mathrm{mg} / \mathrm{g}$, total phenol shows significant differences between $0.60-1.90 \mathrm{mg} / \mathrm{ml}$, correlation. Betaine concentrations were different in varieties. Where betaine was higher, betanine and polyphenol were also higher along with antioxidant capacity (Hájos et al., 2004). Between red coloring matter and total polyphenol concentration, significant correlation was calculated ( $r=0,7577)$ (Sárdi et al., 2009).

Schiebler already discovered betaine in Beta vulgaris in 1869 and since then betaine was observed in several living organisms (Blunden and Gordon 1986, Hougaard et al., 1994) and human cells as well (Lever et al., 1994).

In modern medicine, betaine is an important natural molecule for treating homocysteinuria, alcoholic steatosis, chemically induced liver, lung and skin cancers (Wilcken et al., 1983, Barak et al., 1996, Eikelboom et al., Murakami et al., 1998). This molecule helps to create choline, can help synthesize of carnitine and helps to convert homocysteine into methionine and it takes part in biologic methylation (Finkenstein and Martin 1984, Slow et al., 2004, Awad et al., 1983, Skiba et al., 1982, Evans et al., 2002, Millan and Garrow 1998).

\subsection{Metal elements in tumor}

Metal elements are important in nutrition and prevention of diseases, as anemia could be treated with supplementation of Fe. Concentration of essential metal elements is rigorously regulated in the metabolic pathways in contrary to toxic elements in healthy organisms. Concentration changes of some transition metal elements $\mathrm{Cu}, \mathrm{Fe}, \mathrm{Mn}, \mathrm{Zn}$ and non-metal elements S, Se, P can significantly modify the signal transduction. Therefore, their optimal tissue concentrations are not doubtful and daily intake of these elements from natural sources is very important (Szentmihályi et al., 2000a,b, Máday et al., 2000). These elements are ubiquitous in biological systems and play a key role in the catalysis of redox processes. Heavy metals in higher concentrations may inhibit enzyme activities and influence the acute 
phase protein synthesis and gene expression, as well as the pro-oxidant and antioxidant forms of scavenger molecules. Mainly the free $\mathrm{Fe}(\mathrm{II})$ and $\mathrm{Cu}(\mathrm{I})$ and $\mathrm{Cu}(\mathrm{II})$ redox active metal ions catalyze the formation of reactive oxygen radicals, but they occur in the body in a small amount (Kasprzak et al., 1987). CuZnSOD in the cytoplasm and the nucleus, MnSOD in the mitochondrial matrix, catalase in peroxisomes or in the cytoplasm and glutathione peroxidase in the cytoplasm are known metalloproteins, which take part in the defense mechanism against toxic concentration of free radicals (Yuregir et al., 1994, Schroeder and Cousins 1990, Dinkova-Kostova et al., 2005). Cu occurs in the ceruloplasmin, and it has an oxidase function. It is able to oxidize biogen amines and its phenoxidase activity is also proved (Floris et. al., 2000, Pena, et al., 1999). Zn is a key element in antioxidant superoxide dismutase enzyme as well as Zn-metallothionein, which has hydroxyl scavenging ability (Brando-Neto et al., 1994). Mn also takes part in the enzymatic antioxidant defense system, since the superoxide dismutase enzyme scavenges superoxide anions. In blood, $\mathrm{Mn}(\mathrm{II})$ ions take on the forms of free aqua-complexes or are bounded to albumin, a macroglobulin and other glycoproteins (Critchfield and Keen 1992). Mn(II) is an antioxidant, since in fast reaction it exterminates the alkyl peroxyl radicals formed by the peroxidation of fatty acids, while $\mathrm{Fe}(\mathrm{II})$ ions generate alkoxy and hydroxyl radicals by splitting the $\mathrm{ROOH}$ bond and continue the chain reaction (Siegel and Sigel 1999). Mn(II) ions, similarly to Zn ions, are able to decrease the formation of superoxide radicals by forming $\mathrm{Mn}_{2}(\mathrm{NADPH})$ complexes (Schramm 1986). Metal ions are important for the activation of NF-kappaB, AP-1 and in the cases of NFkappaB proteasome degradation as well as the regulation of IkappaB kinases and other redoxy sytems. The joining of the NF-kappa B to the DNA is the function of the redoxi state of apo 62 cystein in p50 subunit in the DNA-bond domain. This connection is injured by the effect of heavy metals such as $\mathrm{As}, \mathrm{Cd}, \mathrm{Co}, \mathrm{Cr}, \mathrm{Ni}$ and $\mathrm{Pb}$ (Kudrin 2000). The risk of tumor formation is increased in the presence of $\mathrm{Ni}, \mathrm{Cr}$ and As ions, because DNA repair systems are very sensitive targets of these elements (Hartwig 1998). Divalent cations, such as $\mathrm{Zn}, \mathrm{Cu}, \mathrm{Cd}, \mathrm{Mn}$ and $\mathrm{Ni}$ can modulate the function of tumor suppressor protein p53 in vitro (Maehle et al., 1992). The excess of $\mathrm{Zn}$ and Cd cause inhibition of the apoptosis (Chukhlovin et al., 2001).

In several biochemical pathways $\mathrm{Ni}, \mathrm{Cr}$ and As toxic metal elements compete with $\mathrm{Mg}$ ions. Competition between $\mathrm{Ni}(\mathrm{II})$ and $\mathrm{Mg}$ (II) may provide an important mechanism for interfering with DNA-protein interactions involved in the repair process, because the inhibition of DNA repair is partly reversible by the addition of $\mathrm{Mg}$ (II) (Kasprzak et al., 1987, Hartwig et al., 1994). Presumable Ni(II), Co(II) and As(II) ions displace Zn ion in the zincfinger structure of DNA repair enzymes (Hartwig 1998). Ni, Cr and As elements are established carcinogens in humans. These heavy metals can induce adhesion molecules and cytokines (Hayat 1996).

Magnesium deficiency alters calcium homeostasis via $\mathrm{Ca}^{2+} / \mathrm{Mg}^{2+}$ antagonism, leading to transient increase in the concentration of intracellular calcium. Magnesium may act as a physiological ",antioxidant", e.g. against lipoprotein oxidation. The transient increase in the intracellular calcium level induced by magnesium deficiency, enhances the production of pro-oxidant cytokines (IL-1, IL-6, IL-8, TNF- $\alpha,-\beta$ ), different growth factors (EGF- $\alpha$, TGF- $\beta$, NFGF, FGF, PDGF), and interferons (IFN- $\alpha,-\gamma$ ) by activation of phosphoinositol diphosphate $\left(\mathrm{PIP}_{2}\right)$ and MAP kinases (Dolmetsch et al. 1997, Caddell 2000).

The enhanced synthesis of cytokines induces gene expressions of enzymes of reactive oxygen species including NADPH oxidase, xanthine-oxidase/dehydrogenase, 
cyclooxygenase, lipoxygenase, cytochrome P450, NO synthase, proteins containing iron, and superoxide dismutase, copper zinc and manganase enzymes that are regulated at transcripitional level by phosphorylation of transcription factors. On the contrary, the increase in the intracellular magnesium level inhibits the production of pro-oxidant cytokines via the activation of corresponding protein phosphatases, therefore the generation of reactive oxygen species can be attenuated. Therefore the intake of the right amount of magnesium and magnesium-calcium rations is essential.

\subsection{Clinical investigation of table beet supplementation}

Adenocarcinoma of the prostate is still one of the major reasons of cancer-related mortality in populations of Western countries, but the current understanding of its etiology and pathogenesis is still lacking (Jemal et al., 2008).

Although, prostate cancer is silent and creates no early warning symptoms, after the extensive use of serum prostate specific antigen (PSA) testing, it has increasingly been reported at earlier stages. In case of localized prostate cancer, for a man in good condition, radical prostatectomy is the preferred treatment with more than 10 years life expectancy. Furthermore, radical surgery might provide a therapy for well-selected locally advanced prostate cancer. However, it is still not possible to distinguish who is at a high risk of tumor recurrence after primary local therapy, so will not benefit from surgery. In addition it can not be predicted who will benefit from hormonal therapy and who will become soon hormone resistant in cases of advanced prostate cancer. Nowadays, although using more promising indicators to distinguish between surgically curable and oncologically treatable prostate cancer, there has not still been an optimal factor found which would tell us the prognosis (Barqawi et al., 2004, Nyirády and Romics 2009a,b).

Several papers report effect of table beet supplements in the improvement of quality of life of different diseases, although their physiological investigation is poor. Table beet affects numerous biochemical reaction ways, enzymes and metabolic-synthesis occurring in vivo (Kuramoto et al., 1996, Váli et al., 2007, Blázovics et al., 2007b). In this clinical study 10g natural table beet lyophilized product was given twice daily for 1 month for 24 patients (mean age $68 \pm 8$ years) with hormone-resistant and metastatic prostate cancer treated with taxan chemotherapy, who reported their complaints themselves first, mean $3.6 \pm 2.8$ years before. 18 men's data were amenable after treatment for evaluation. (Permission number of clinical study: Semmelweis University 127/2006.) The lyophilized product was purchased from commercial service (Permission number: 1361/004/2003 BFAEE) GPS Powder Kft. Budapest, Hungary) (Nyirády et al., 2010).

In addition to routine laboratory examination values of $\mathrm{HbA1c}, 9$ cytokines and levels of 3 growth factors, the global parameters of redox-homeostasis, few elements, Zn- and level of free protoporphyrin, trans-methylation processes were determined before and one month after treatment.

Results showed that in most of the patients the favorable impact of beet was enforced and significantly high levels of $\mathrm{Zn}$ - and free protoporphyrin decreased; furthermore transmethylation processes fastened which all characterize patients with tumor (Nyirády et al., 2010). Table1. shows the element concentrations of lyophilized table beet powder applied in human study.

The calculated metal element intake concentration, on the basis of daily dose of lyophilized table beet powder, is very low. The essential element concentrations compared to the 


\begin{tabular}{|c|c|c|c|}
\hline elements & $\begin{array}{c}\text { lyophilized table } \\
\text { beet powder }(\mu \mathrm{g} / \mathrm{g})\end{array}$ & daily intake $(\mu \mathrm{g})$ & $\begin{array}{c}\text { percentage of daily needs *, } \\
\text { and percentage of average } \\
\text { daily intake }\end{array}$ \\
\hline $\mathrm{Al}$ & $21.62 \pm 4.60$ & 432.4 & $13.1^{* *}$ \\
\hline $\mathrm{B}$ & $8.56 \pm 4.91$ & 171.2 & $7.4^{*}$ \\
\hline $\mathrm{Ba}$ & $3.79 \pm 0.16$ & 75.8 & $5.1^{* *}$ \\
\hline $\mathrm{Ca}$ & $701.0 \pm 15.6$ & 14020 & $1.4^{*}$ \\
\hline Co & $0.146 \pm 0.003$ & 2.92 & $0.5^{* *}$ \\
\hline $\mathrm{Cr}$ & $0.311 \pm 0.037$ & 6.22 & $17.8^{*}$ \\
\hline $\mathrm{Cu}$ & $3.13 \pm 0.59$ & 62.6 & $6.9^{*}$ \\
\hline $\mathrm{Fe}$ & $17.68 \pm 0.03$ & 353.6 & $4.4^{*}$ \\
\hline K & $8057 \pm 512$ & 161140 & $3.4^{*}$ \\
\hline $\mathrm{Li}$ & $<0.1$ & & \\
\hline $\mathrm{Mg}$ & $829.9 \pm 9.7$ & 16598 & $4.0^{*}$ \\
\hline $\mathrm{Mn}$ & $9.99 \pm 0.11$ & 199.8 & $9.1^{*}$ \\
\hline Mo & $0.205 \pm 0.059$ & 4.1 & $9.1^{*}$ \\
\hline $\mathrm{Na}$ & $661.4 \pm 30.9$ & 13228 & $0.9^{*}$ \\
\hline $\mathrm{Ni}$ & $0.469 \pm 0.125$ & 9.38 & $9.4^{* *}$ \\
\hline $\mathrm{P}$ & $1545 \pm 83$ & 30900 & $4.4^{*}$ \\
\hline Se & $0.142 \pm 0.011$ & 2.84 & $5.2^{*}$ \\
\hline $\mathrm{Si}$ & $53.96 \pm 1.48$ & 1079.2 & $5.4^{* *}$ \\
\hline $\mathrm{Sr}$ & $3.89 \pm 0.05$ & 77.8 & $1.7^{* *}$ \\
\hline $\mathrm{Zn}$ & $6.09 \pm 0.21$ & 121.8 & $1.1^{*}$ \\
\hline
\end{tabular}

Table 1. Element concentration of lyophilized table beet powder (dose 20g/day) ; (mean $\pm S D)$.

proposed daily intake (RDA, DRI) and non-essential or toxic element concentrations compared to average daily intake, can be seen in Table 1 . The important intake $(>15 \%)$ can be considered in the case of $\mathrm{Cr}$.

Alteration of metal element homeostasis may elevate the risk of prostate diseases, e.g. intake of high amount of Fe or Zn deficiency may increase the oxidative processes in which NFkappaB, IL-6 and IL-8 etc. are activated and the incidence of prostate cancer elevates as well as toxic metal elements (Salnikow et al., 2008). Zn depletion in the prostate's peripheral zone is found to correlate with the Gleason score.

Erythrocyte element status of patients with prostate cancer significantly changed versus controls in cases of $\mathrm{Al}(1.90 \pm 1.67$ vs $0.537 \pm 0.260), \mathrm{Ni}(0.722 \pm 0.565$ vs $0.265 \pm 0.195)$ and $\mathrm{Pb}$ $(0.309 \pm 0.301$ vs $0.094 \pm 0.053)$, and these ion concentrations were significantly high in prostate cancer patients with PSA>9 (Nyirády et al., 2009b).

Toxic metal elements and free radicals influence the function of several receptors and genes such as tyrosine kinases, epidermal growth factor (EGF), platelet-derived growth factor (PDGF), vascular endothelial growth factor (VEGF); src and ras genes and signal proteins, nuclear factors - kappaB (NF-kappaB), activated protein-1 (AP-1), p53, nuclear factor of activated cells family (NFAT), hypoxia induced factor (HIF-1) (Suzuki 1997, Atmane 2003). The plasma concentrations of Ca-, $\mathrm{Cu}-$ and $\mathrm{Mg}$ in patients did not change significantly during the treatment and they were between the normal range in all cases. Nevertheless, the Fe concentration decreased significantly by the effect of table beet supplementation and 
moved toward the normal value range. The Se level increased by the effect of treatment, although it reached the normal value only in some cases. The $\mathrm{Zn}$ concentration decreased significantly, the mean value was in the normal range. These data show that the metal ion homeostasis begins to restore, the metal ions stay in cells compartments by the effect of table beet consumption (Table 2.).

\begin{tabular}{|c|c|c|c|c|c|c|}
\hline \multirow{2}{*}{ groups } & \multicolumn{1}{|c|}{$\begin{array}{c}\mathrm{Ca} \\
\text { normal } \\
\text { value:98 }\end{array}$} & $\begin{array}{c}\mathrm{Cu} \\
\text { normal } \\
\text { value:1.2 }\end{array}$ & $\begin{array}{c}\mathrm{Fe} \\
\text { normal } \\
\text { value:1.1 }\end{array}$ & $\begin{array}{c}\mathrm{Mg} \\
\text { normal } \\
\text { value:22 }\end{array}$ & $\begin{array}{c}\mathrm{Zn} \\
\text { normal } \\
\text { value:1.4 }\end{array}$ & $\begin{array}{c}\text { Se* } \\
\text { normal } \\
\text { value:0.08 }\end{array}$ \\
\cline { 2 - 7 }$(\mathrm{mg} / \mathrm{kg})$ & \multicolumn{5}{|c|}{} \\
\hline $\begin{array}{c}\text { control } \\
(\mathrm{N}=9)\end{array}$ & $61.38 \pm 22.85$ & $0.79 \pm 0.25$ & $4.37 \pm 1.47$ & $32.09 \pm 10.80$ & $7.22 \pm 3.22$ & $0.080 \pm 0.026$ \\
\hline $\begin{array}{c}\text { metastatic } \\
\text { postate } \\
\text { tumor } \\
\text { (N=18) }\end{array}$ & $77.82 \pm 11.03$ & $1.25 \pm 0.28$ & $12.52 \pm 9.63$ & $21.47 \pm 3.51$ & $1.46 \pm 0.60$ & $0.011 \pm 0.006$ \\
\hline $\begin{array}{c}\text { metastatic } \\
\text { postate } \\
\text { tumor }+ \\
\text { table beet } \\
\text { (N=18) }\end{array}$ & $77.02 \pm 16.44$ & $1.17 \pm 0.37$ & $5.49 \pm 3.83$ & $20.95 \pm 4.93$ & $1.03 \pm 0.44$ & $0.050 \pm 0.061$ \\
\hline
\end{tabular}

significance $(\mathrm{p}<0.05)^{*} ;($ mean $\pm \mathrm{SD})$.

Table 2. Effect of table beet treatment on the plasma element concentrations of metastatic prostate cancer patients with taxan chemotherapy.

IFN- $\alpha, \beta, \gamma$, IL-1 $\alpha, \beta$, IL-6, IL-10, IL-12, TNF- $\alpha, \beta$, MIF and chemokines inflammatory cytokines, which initiate the activation of specific immune cells and regulate their differentiations (Haddad 2002). Chemokines affect the increasing of cell adhesion and chemotaxis, as well as activation of effector leucocytes are increased by them. During leucocyte activation, free radicals and lipid derivatives are liberated (Malaguarnera 2001).

Special components (betaine, folic acid, Fe, flavonoids and vitamins) of table beet could modify the erythrocyte total scavenger capacity and element concentrations as well as improve the transmethylation ability.

The levels of proinflammatory cytokines shown of a declining tendency, but these changes were not significant (IL1a P=0.084; IL6 P=0.154; IL8 P=0.578). The effect was beneficial. Measured parameters of anti-inflammatory cytokines also decreased (IL2 $\mathrm{P}=0.255 ; \mathrm{P}=0.38$; $\mathrm{P}=0.204)$. At the same time VEGF was not changed, although EGF was higher $(\mathrm{p}=0.003)$, and PSA ( $P=0.441)$ was elevated non significantly after supplementation. The levels of IL-6, CRP, IFNG and MCP1 were decreased in small amounts in the sera; these were disadvantageous results (Nyirády et al., 2010).

Consumption of beetroot decreased the proinflammatory cytokines and in some patients $(44 \%)$ increased the level of IL2. In other patients (52\%) we measured lower level of PSA. There were hopeful results, but increased EGF levels draw attention to the fact, that further investigations and correlation analysis must be performed, in which beneficial effects on patients can be observed. Data can be seen in Table 3. 


\begin{tabular}{|c|c|c|c|c|}
\hline \multirow{2}{*}{ parameters } & \multicolumn{4}{|c|}{ patient groups } \\
\cline { 2 - 5 } & $\begin{array}{c}\text { healthy controls } \\
(\mathrm{N}=26)\end{array}$ & $\begin{array}{c}\text { early stage } \\
(\mathrm{N}=28)\end{array}$ & $\begin{array}{c}\text { metastatic } \\
(\mathrm{N}=18)\end{array}$ & $\begin{array}{c}\text { metastatic } \\
\text { table beet } \\
(\mathrm{N}=8)\end{array}$ \\
\hline IL-1 alpha $(\mathrm{pg} / \mathrm{ml})$ & $0.64 \pm 0.50$ & $0.10 \pm 0.30$ & $0.54 \pm 0.42$ & $0.35 \pm 0.17$ \\
\hline IL-1 beta $(\mathrm{pg} / \mathrm{ml})$ & $1.57 \pm 1.3$ & $0.80 \pm 2.20$ & $1.18 \pm 1.60$ & $0.42 \pm 0.50$ \\
\hline IL-2 $(\mathrm{pg} / \mathrm{ml})$ & $4.18 \pm 2.80$ & $4.70 \pm 5.60$ & $7.80 \pm 4.4$ & $5.5 \pm 7.2$ \\
\hline IL-4 $(\mathrm{pg} / \mathrm{ml})$ & $4.56 \pm 1.84$ & $2.30 \pm 5.40$ & $4.70 \pm 2.05$ & $4.0 \pm 2.01$ \\
\hline IL-6 $(\mathrm{pg} / \mathrm{ml})$ & $1.51 \pm 1.34$ & $1.20 \pm 2.30$ & $14.2 \pm 24.20$ & $5.6 \pm 6.5$ \\
\hline IL-8 $(\mathrm{pg} / \mathrm{ml})$ & $25.21 \pm 16.16$ & $9.10 \pm 16.30$ & $31.20 \pm 87.00$ & $25.3 \pm 29.6$ \\
\hline IL-10 $(\mathrm{pg} / \mathrm{ml})$ & $1.08 \pm 0.69$ & $0.20 \pm 0.50$ & $1.54 \pm 1.91$ & $0.88 \pm 0.99$ \\
\hline TNF-alpha $(\mathrm{pg} / \mathrm{ml})$ & $7.45 \pm 4.23$ & $3.00 \pm 3.60$ & $3.41 \pm 1.65$ & $3.50 \pm 0.98$ \\
\hline VEGF $(\mathrm{pg} / \mathrm{ml})$ & $190 \pm 150$ & $183 \pm 94$ & $272 \pm 116$ & $282 \pm 160$ \\
\hline IFNG $(\mathrm{pg} / \mathrm{ml})$ & $1.78 \pm 1.41$ & $0.8 \pm 1.50$ & $4.28 \pm 4.21$ & $2.21 \pm 1.97$ \\
\hline MCP1 $(\mathrm{pg} / \mathrm{ml})$ & $346 \pm 158$ & $306 \pm 93$ & $347 \pm 171$ & $323 \pm 157$ \\
\hline EGF $(\mathrm{pg} / \mathrm{ml})$ & $212 \pm 81$ & $66.8 \pm 58.3^{*}$ & $59.3 \pm 40.4^{*}$ & $110 \pm 58.8^{* *}$ \\
\hline CRP $(\mathrm{mg} / \mathrm{l})$ & $<5$ & $5.6 \pm 12.8$ & $14.4 \pm 24.9$ & $5.9 \pm 4.9$ \\
\hline PSA $(\mathrm{pg} / \mathrm{ml})$ & $<2$ & $10.66 \pm 7.79^{*}$ & $93 \pm 120^{* *}$ & $133.5 \pm 182.5^{* *}$ \\
\hline
\end{tabular}

significance $(\mathrm{p}<0.05)$ : control vs *; * $\mathrm{vs}^{* *} ;($ mean $\pm \mathrm{SD})$.

Table 3. Immune parameters of prostate cancerous patients with and without table beet treatment in different stages and PSA levels.

Table 4. summarizes the redox parameters of patient groups. Table beet consumption moderated the erythrocyte free radical level in tendency and significant difference was observed in plasma in treated group compared to control. The large SD means that metastatic processes are different in time. There were no differences between $\mathrm{HbA1c}$ values.

\begin{tabular}{|l|c|c|c|}
\hline \multicolumn{1}{|c|}{ groups } & $\begin{array}{c}\text { plasma } \\
(\mathrm{RLU} \%)\end{array}$ & $\begin{array}{c}\text { erythrocyte } \\
(\mathrm{RLU} \%)\end{array}$ & $\begin{array}{c}\text { HbA1c } \\
(\%)\end{array}$ \\
\hline $\begin{array}{l}\text { Control } \\
(\mathrm{N}=11)\end{array}$ & $4.51 \pm 1.25$ & $73.19 \pm 12.09$ & $<6.1$ \\
\hline $\begin{array}{l}\text { postate tumor } \\
\text { (metastatic) } \\
(\mathrm{N}=18)\end{array}$ & $3,25 \pm 4,93$ & $71,78 \pm 60,07$ & $6,1 \pm 0,7$ \\
\hline $\begin{array}{l}\text { postate tumor } \\
\text { (metastatic) }+ \\
\text { table beet } \\
(\mathrm{N}=18)\end{array}$ & $1,69 \pm 1,39^{*}$ & $54,71 \pm 43,81$ & $6,1 \pm 0,9$ \\
\hline
\end{tabular}

significance $(\mathrm{p}<0.05)$ control $\mathrm{vs}^{*} ;($ mean $\pm \mathrm{SD})$.

Table 4. Effect of table beet treatment on the redox parameters of prostate cancer patients with taxan chemotherapy. 
On the basis of linear regression between chemiluminescent intensity (RLU\%) and free protoporphyrin/Zn-protoporphyrin ratio, where $y=-237.49 x+156.08$ and $R^{2}=0.6177$ were calculated, significance could be observed. If the free protoporphyrin and $\mathrm{HCHO}$ ration was analyzed, the linear regression was better: $y=-272.77 x+1024.6$ and $R^{2}=0.8331$ (Nyirády et al., 2009).

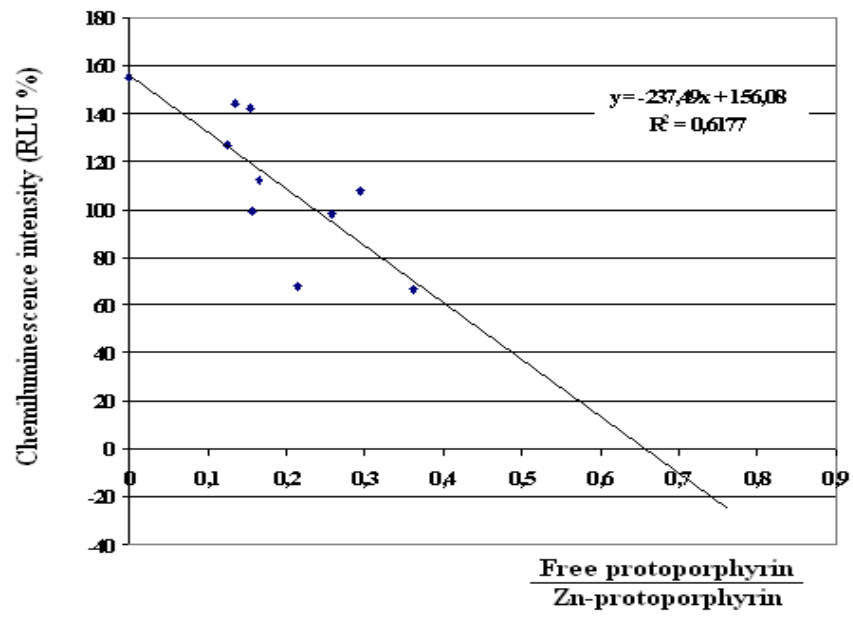

Fig. 2. Correlation between free protoporphyrin/Zn-protoporphyrin and chemiluminescent intensity (RLU\%) in erythrocyte of cancerous patients.

Free protoporphyrin is accumulated generally in more cancerous cells than in healthy ones and autofluorescence lifetime is extended in cancer tissues (Chang et al., 2005). The results showed that in cancerous patients protoporphyrin - according to concentration - induces free radicals in small concentration and scavenges in higher concentration.

Accumulation of toxic metal elements and high protoporphyrin and Zn-protoporphyrin concentrations and low bond $\mathrm{HCHO}$ in erythrocyte with high PSA level mean wrong diagnosis.

According to the findings it seems that moderate and permanent consumption of table beet product affect favorably the life expectancy of patients, improves the erythrocyte function by the increasing methyl groups and diminishes the Zn-protoporphyrin and free protophorphyrin concentrations, but because of the increasing values of EGF and PSA in $44 \%$ of patients with bone metastasis, carefulness is needed. Further examinations are needed in this field.

Table 5. shows the erythrocyte Zn-protoporhyrin-, free- protoporhyrin-, erythrocyte formaldehyde - concentrations and PSA levels of cancerous patients with and without table beet treatment in different stages.

Before the table beet treatment, the HCHO concentration was $1.02 \times 10^{-3} \pm 2,73 \times 10^{-4}$ $\mu \mathrm{mol} / \mathrm{mg}$ erythrocyte, and after treatment the HCHO concentration was $3.72 \times 10^{-3} \pm 1,08 \times$ $10^{-3} \mathrm{\mu mol} / \mathrm{mg}$ erythrocyte. Consequently, the HCHO concentration was elevated and therefore the function of erythrocyte was improved. 


\begin{tabular}{|c|c|c|c|c|}
\hline patients & $\begin{array}{c}\text { Zn- } \\
\text { protoporhyrin } \\
\text { (nmol/l ery) }\end{array}$ & $\begin{array}{c}\text { free- } \\
\text { protoporhyrin } \\
(\text { nmol/l ery) }\end{array}$ & $\begin{array}{c}\text { erythrocyte } \\
\text { formaldehyde } \\
(\mu \mathrm{mol} / \mathrm{ml})\end{array}$ & $\begin{array}{c}\text { PSA } \\
(\mathrm{ng} / \mathrm{ml})\end{array}$ \\
\hline $\begin{array}{c}\text { healthy control } \\
(\mathrm{N}=14)\end{array}$ & nd & nd & $\begin{array}{c}1.52 \times 10^{-2} \\
\pm 1.25 \times 10^{-3}\end{array}$ & $\mathrm{nv}$ \\
\hline $\begin{array}{c}\text { prostate tumor } \\
\text { (histology -) } \\
(\mathrm{N}=10)\end{array}$ & $1282 \pm 513^{*}$ & $325 \pm 50^{*}$ & $\begin{array}{c}1.06 \times 10^{-2 *} \\
\pm 1.44 \times 10^{-3}\end{array}$ & $9.66 \pm 5.28^{*}$ \\
\hline $\begin{array}{c}\text { prostate tumor } \\
\text { (histology }+) \\
(\mathrm{N}=30)\end{array}$ & $1043 \pm 372^{*}$ & $582 \pm 782^{*}$ & $\begin{array}{c}7.830 \times 10^{-3 * *} \\
\pm 2.56 \times 10^{-3}\end{array}$ & $13.68 \pm 21.91^{*}$ \\
\hline $\begin{array}{c}\text { prostate tumor } \\
\text { (metastatic) } \\
(\mathrm{N}=18)\end{array}$ & $1470 \pm 768^{*}$ & $334 \pm 420^{*}$ & $\begin{array}{c}1.02 \times 10^{-3 * * *} \\
\pm 2.73 \times 10^{-4}\end{array}$ & $93 \pm 120^{* *}$ \\
\hline $\begin{array}{c}\text { prostate tumor } \\
\text { (metastatic) } \\
\text { table beet } \\
\text { (N=18) }\end{array}$ & $857 \pm 308^{*}$ & $301 \pm 276^{*}$ & $\begin{array}{c}3.72 \times 10^{-3} \pm \\
* * * * 1.08 \times 10^{-3}\end{array}$ & $133.5 \pm 182.5^{* *}$ \\
\hline
\end{tabular}

nd non detected; nv value is in normal range (normal value of PSA is $0.01-4.00 \mathrm{ng} / \mathrm{ml}) ;($ mean $\pm \mathrm{SD}$ ) significance: control vs *;*;***; * vs **; ** $\mathrm{vs}^{* * *},{ }^{* * * *}$.

Table 5. Erythrocyte parameters of cancerous patients with and without table beet treatment in different stages.

\section{Conclusion}

$\mathrm{HCHO}$ and protoporphyrin concentrations and the induced free radical level of erythrocytes are very important indexes in cancer. The changes of their concentrations mean changes in tumor stages.

Generally the valuation of beneficial effects of nutrition supplements on patient life quality in tumor is empirical, and clinical studies are very rare. Beta vulgaris L. ssp. esculenta var. rubra is rich in bioactive compounds therefore it affects numerous biochemical reactions, enzyme activities and metabolic pathways. Homeostasis depends on table beet metal ion concentrations. This vegetable can be considered as a functional food, because among others, table beet is a good alimentary factor in cases of fatty liver, it has beneficial lipid lowering effects in obesity. Dietary betaine may need to be factored into the dietary sources of labile methyl groups and increase the methyl-pool. Treatment of betaine lowered plasma homocysteine concentration in homocystinuric patients.

The favorable impact of Beta vulgaris is enforced because significantly high levels of Zn- and free protoporphyrin decrease and furthermore trans-methylation processes fasten in cancerous patients. These results clearly verify that iron, folic acid and betaine components as well as colorful compounds with antioxidant activity of table beet extract demand more attention as a preventive therapy in chemotherapy induced anemia. Table beet will have a great impact and application in human cancer, but because of the increasing values of EGF close medical control is necessary for patients especially during chemotherapy. 


\section{Acknowledgements}

This study was supported by the Health Sciences Scientific Committee ETT 354/2006, ETT 012/02, ETT 02/02.

Authors express their thanks to Mrs. Sarolta Bárkovits, Mrs. Edina Pintér and Mrs. Judit Sablyán for their excellent technical assistance.

\section{Abbreviations}

$\mathrm{CRP}=\mathrm{C}$ reactive protein

DNA $=$ deoxy-ribonucleic acid

EGF $=$ epidermal growth factor

$\mathrm{HbA} 1 \mathrm{c}=$ glycated hemoglobin

$\mathrm{HCHO}=$ formaldehyde

IBD = inflammatory bowel diseases

IFNG $=$ interferon-gamma

IL-1 alpha/beta, IL-2, IL-4, IL-6, IL-8, IL-10, = interleukins

MCP-1 = monocyte chemoattractant protein-1

PSA $=$ prostate-specific antigen

RLU $=$ relative light unit

TNF- $\mathrm{a}=$ tumor necrosis factor-alpha

\section{References}

Abate, C., Patel, L., Rauscher, I.F.J., Curran, T. (1990). Redox regulation of Fos and Jun DNA: binding activity in vitro. Science, Vol.249, No. 4973, (Sept 1990), pp. 1157-1161, ISSN: 0036-8075

Atmane, N., Dairou, J., Paul, A., Dupret, J.M., Rodrigues-Lima, F. (2003). Redox regulation of the human xenobiotic metabolizing enzyme arylamine $\mathrm{N}$-acetyltransferase 1 (NAT1). Reversible inactivation by hydrogen peroxide. Journal of Biological Chemistry, Vol. 278, No. 37, (Jun 2003), pp. 35086-35092, ISSN: 0021-9258

Awad, W.M.J., Whitney, P.L., Skiba, W.E., Mangum, J.H., Wells, M.S. (1983). Evidence for direct methyl transfer in betaine:homocysteine S-methyl-transfrease. Journal of Biological Chemistry, Vol. 258, No.258, (1983 Nov 10), pp. 12790-12792, ISSN: 00219258

Azzi, A., Gysin, R., Kempná, P., Munteanu, A., Villacorta, L., Visarius, T., Zingg, J,M. (2004). Regulation of gene expression by alpha-tocopherol.. Biological Chemistry, Vol.385, No 7, (Jul 2004), pp. 585-591, ISSN: 0021-9258

Barak, A.J., Beckenhauer, H.C., Tuma, D.J. (1996). Betaine, ethanol and the liver: a review. Alcohol, Vol.13, No.4, (Jul-Aug 1996), pp. 395-398, ISSN: 0741-8329

Barqawi, A., Thompson, I.M., Crawford, E.D. (2004). Prostate cancer chemoprevention, an overview of United States trials, Journal of Urology, Vol.171, No.2, (Febr 2004), pp. S5-8, ISSN: 0022-5347

Baylin, S.B., Herman, J.G., Graff, J.R., Vertino, P.M., Issa, J.P. (1997). Alterations in DNA methylation: a fundamental aspect of neoplasia. Advances in Cancer Resesearch, Vol. 72, No.72, pp. 141-196, ISSN: 0065-230X 
Bastian, P.J., Palapattu, G.S., Yegnasubramanian, S., et al. (2008). CpG island hypermethylation profile in the serum of men with clinically localized and hormone refractory metastatic prostate cancer. Journal of Urology, Vol. 179, No.2, (Febr 2008), pp. 529-534, ISSN: 0022-5347

Blázovics, A. (2011). Small molecules in cancer therapy: cytotoxics and molecularly targeted agents. Current Signal Transduction Therapy, Vol.6, No.1, (Jan 2011), pp. 2-19, ISSN: 1574-3624

Blázovics, A., Kovács, Á., Lugasi, A. (2007a). The effect of short and long term antioxidant treatments on redox homeostasis in experimental and clinical studies. In: Nutritional Research Advances, (Ed.) Sarah V. Watkins, Nova Science Publisher, ISBN: 978-1-60021-516-2, Chapter 4, pp. 1-34, USA

Blázovics, A., Kovács, A., Szilvás, Á. (2009). Redox homeostasis in gastrointestinal diseases. Acta Biologica. Szegediensis Vol. 53, Suppl. 1, 3-6, pp. 41-45, ISSN: 1588-4082

Blázovics, A., Kovács, Á., Lugasi, A., Hagymási, K., Bíró, L., Fehér, J. (1999). Antioxidant defence in erythrocytes and plasma of patients with active and quiescent Crohn's disease and ulcerative colitis: A chemiluminescence study. Clinical Chemistry, Vol.6, No.45, pp. 895-896, ISSN: 0009-9147

Blázovics, A., Nyirády, P., Bekő, G., Székely, E., Szilvás, Á., Kovács-Nagy, E., Horváth, A., Szúcs, M., Romics, I., Sárdi, É. (2011). Changes in erythrocyte transmethylation ability are predictive factors for tumor prognosis in prostate cancer, Croatica Chemica Acta, Vol. 84, No.3. pp. 127-131, ISSN: 001-1643

Blázovics, A., Sárdi, E., Szentmihályi, K., Váli, L., Takács-Hájos, M., Stefanovits-Bányai, E. (2007b). Extreme consumption of Beta vulgaris var. rubra can cause metal ion accumulation in the liver. Acta Biologica Hungarica, Vol.58, No.3, pp. 281-286, ISSN: 0236-5383

Blázovics, A., Szilvás, Á., Székely, Gy., Tordai, E., Székely, E., Czabai, G., Pallai, Zs., Sárdi É. (2008). Important bioactive molecules of erythrocytes in colorectal cancer patients after colectomy. The Open Medicinal Chemistry Journal, No.2, (Febr 2008), pp. 6-10, ISSN: $1874-1045$

Blunden, G., Gordon, S.M. (1986). Betaines and their sulphonio analogues in marine algae. Progress in Phycological Research, Vol.4, pp. 41-80, ISSN: 0167-8574

Bobek, P., Galbavy, S., Mariássyová M. (2000). The effect of red beet (Beta vulgaris var. rubra) fiber on alimentary hypercholesterolemia and chemically induced colon carcinogenesis in rats. Nahrung, Vol.44, No.3 S. (Jul 2000), pp. 184-187, ISSN: 0027$769 X$

Boyd, J.N., Babish, J.G., Stoewsand, G.S. (1982). Modification by beet and cabbage diets of aflatoxin $\mathrm{B}_{1}$-induced rat plasma a-foetoprotein elevation, hepatic tumorigenesis, and mutagenicity of urine. Food and Chemical Toxicology, Vol.20, No.1, (Feb 1982), pp. 47-52, ISSN: 0278-6915

Brando-Neto, J., Stefan, V., Mendoca, B.B. et al. (1995). The essential role of zink in growth, Nutrition Research, Vol. 15, No.3, (Marc 1995), pp. 335-338, ISSN: 0271-5317

Caddell, J.L. (2000). Geriatric cachexia: a role for magnesium deficiency as well as for cytokines? American Society for Clinical Nutrition, Vol. 71 No.3, (Marc 2000), pp. 851852, ISSN: 0212-1611 
Cai, Y., Sun, M., Corke, H. (2001). Antioxidant activity of betalains from plants the Amaranthaceae. Journal of Agricultural and Food Chemistry, Vol.51, No.49, (Apr 2003), pp. 2288-2294, ISSN: 1579-4377

Calvisi, D.F., Ladu, S., Gorden, A., Farina, M., Lee, J.S., Conner, E.A., Schroeder, I., Factor, V.M., Thorgeirsson, S.S. (2007). Mechanistic and prognostic significance of aberrant methylation in the molecular pathogenesis of human hepatocellular carcinoma, Journal of Clinical Investigation, Vol. 117, No.9, (Sept 2007), pp. 2713-2722, ISSN: 0895-4356

Chang, C.L., You, C., Chen, H.M., Chiang, C.P., Chen, C.T., Wang, C.Y. (2004). Autofluorescence lifetime measurement on oral carcinogenesis. Conference Publications - IEEE Engineering in Medicine and Biology Society, Vol. 4, pp. 23492351. ISSN: $1557-170 X$.

Chen, R.Z., Pettersson, U., Beard, C., Jackson-Grusby, L., Jaenisch, R. (1998). DNA hypomethylation leads to elevated mutation rates. Nature. Vol.395, No.6697, (Sept 1989), pp. 89-93, ISSN: 0028-0836

Chukhlovin, A.B., Tokalov, S.V., Yagunov, A.S., Westendorf, J., Reincke, H., Karbe, L. (2001). In vitro suppression of thymocyte apoptosis by metal-rich complex environmental mixtures: potential role of zinc and cadmium excess. The Science of The Total Environment, Vol.281, No.1-3, (Dec 2001), pp. 153-163, ISSN: 0048-9697

Critchfield, J.W., Keen, C.L. (1992). Manganese ${ }^{+2}$ exhibits dynamic binding to multiple ligands in human plazma. Metabolism: Clinical and Experimental, Vol.41, No10,(Oct 1992), pp. 1087-1092 ISSN: 0026-0495.

Delerive, P., Furman, C., Teissier, E., Fruchart, J., Duriez, P., Staels, B. (2000). Oxidized phospholipids activate PPARa in a phospholipase A2-dependent manner. FEBS Letters, Vol. 471, No.1, (Apr 2000), pp. 34-38, ISSN: 0014-5793

Dinkova-Kostova, AT, Holtzclaw, W.D., Wakabayashi, N. (2005). Keap1, the sensor for electrophiles and oxidants that regulates the phase 2 response, is a zinc metalloprotein. Biochemistry. Vol.10, No.44, (May 2005), pp. 6889-6899, ISSN: 0001527X

Dolmetsch, R.E., Lewis, R.S., Goodnow, C.C., Healy, J.I. (1997). Differential activation of transcription factors induced by $\mathrm{Ca} 2+$ response amplitude and duration. Nature, No.386, (Apr 1997), pp. 855-858, ISSN: 0028-0836

Eikelboom, J.W., Lonn, E., Yusuf, S. (1999). Homocysteine and cardiovascular disease: a critical review of the epidemiologic evidence. Annals of Internal Medicine, Vol.131, No. 7, (Sept 1999), pp. 363-375, ISSN: 0003-4819

Evans, J.C., Huddler, D.P., Jiracek, J., Castro, C., Millian, N.S., Garrow, T.A., Ludwig, M.L. (2002). Betaine-homocysteine methyltransferase zinc in distorted barrel. Structure, Vol.10, No.9, (Sept 2002), pp. 1159-1171, ISSN:0022-2860

Finkenstein, J.D., Martin, J.J. (1984). Inactivation of betaine-homocysteine methyltransferase by adenosylmethionine and adenosylethionine. Biochemical and Biophysical Research Communication, Vol.118, No.118, (Jan 1984), pp. 14-19, ISSN: 0006-291X

Floris, G., Medda, R., Padiglia, A., et al., (2000). The physiological significance of ceruloplasmin. A possible therapeutical approach. Biochemical Pharmacology, Vol 60, No.12, (Dec 2000), pp. 1735-1741, ISSN: 0006-2952

Frank, T., Stintzing, F.G., Carle, R., Bitsch, I., Quaas, D., Strass, G., Bitsch, R., Netzel, Z. (2005). Urinary pharmacokinetics of betalains following consumption of red beet 
juice in healthy humans. Pharmacological Research, Vol.52 No.4, (Oct 2005), pp. 290297, ISSN: 1043-6618

Gersbeck, N., Schönbeck, F., Tyihák, E. (1989). Measurement of formaldehyde and its main generators in Erysiphe graminis infected barley plants by planar chromatographic techniques. Journal of Planar Chromatography, Vol. 2, No.1, pp. 86-89, ISSN:1789-0993

Griffiths, H.R., Lunec, J. (2001). Ascorbic acid in the 21st century: more than a simple antioxidant. Environmental Toxicology and Pharmacology, .Vol. 10, No.4, (Sept 2001), pp. 173-182, ISSN: 1382-6689

Haddad, J.J. (2002). Oxygen-sensitive pro-iflammatory cytokines, apoptosis signaling and redox-responsive transcription factors in development and pathophysiology. Cytokines Cellular and Molecular Therapy, Vol. 7, No.1, (Marc 2002, pp. 1-14, ISSN: $1368-4736$

Hájos, M.T., Varga, I.Sz., Lugasi, A., Fehér, M., Bányai, É.S. (2004): Correlation between pigment contents and FRAP values in beet root (Beta vulgaris ssp. esculenta var. rubra). International Journal of Horticultural Science, Vol.10, No.4, pp. 85-89, ISSN: 1585-0404

Hagymási, K., Blázovics, A., Lengyel, G., Kocsis, I., Fehér, J. (2001). Oxidative damage in alcoholic liver disease. European Journal of Gastroenterology and Hepatology, Vol.13, No.1, (Jan 2001), pp. 49-53, ISSN: 0954-691X

Hartwig, A. (1998). Carcinogenicity of metal compounds: Possible role of DNA repair inhibition. Toxicology Letters, Vol.102-103, (Dec 1998), pp. 235-239 ISSN: 0378-4274

Hartwig, A., Mullenders, L.H.F., Schlepegrell, R., Kasten, U., Beyersmann, D. (1994). Nickel(II) interferes with the incision step in nucleotide excision repair in mammalian cells. Cancer Research, Vol. 54, No.15, (Aug 1994), pp. 4045-4051, ISSN: 0008-5472

Hayat, L.(1996). Cations in malignant and benign brain tumors. Journal. Environmental Science and Health. Part. A Vol. 31, No.8,(Aug 1996), pp. 1831-1840.ISSN: 1093-4529

Hougaard, L., Anthoni, U., Christophersen, C., Larsen, C., Lever, C., Lever, P.H.N. (1991). Characterization and quantitative estimation of quaternary ammonium compounds in marine demosponges. Comparative Biochemistry and Physiology Part B: Biochemistry and Molecular Biology, Vol.99, No.2, (2, 1991), pp. 469-472, ISSN: 1096-4959

Huszti, Z., Tyihák, E. (1986). Formation of formaldehyde from S-adenosyl-L-(mehyl-3H) methionine during enzymatic transmethylation of histamine. FEBS Letters. Vol.209, No.2, (Dec 1986), pp. 362-366, ISSN: 0014-5793

Jemal, A., Siegel, R., Ward, E., Hao, Y., Xu, J., Murray, T., Thun, M. (2008). Cancer statistics, CA: a Cancer Journal for Clinicians, Vol.58, No.2, pp. 71-96, ISSN:0007-9235

Kanner, J., Harel., S., Granit, R. (2001). Betalains-A New class of Dietary cationized antioxidants. Journal of Agriculture and Food Chemistry, Vol. 49, No.11, (2001 Nov), pp. 5178-5185, ISSN: 0021-8561

Kapadia, G.J., Azuine, M.A., Sridhar, R., Okuda, Y., Tsuruta, A., Ichiishi, E., Mukainake, T., Takasaki, M., Konoshima, T., Nishino, H., Tokuda, H. (2003). Chemoprevention of DMBA-induced UV-B promoted, NOR-1-induced TPA promoted skin carcinogenesis, and DEN-induced phenobarbital promoted liver tumors in mice by extract of beetroot. Pharmacological Research, Vol.47, No.2, (2003 Feb), pp. 141-148, ISSN: 1043-6618 
Kasprzak, K.S., Waalkes, M.P., Poirier, L.A. (1987). Effect of essential divalent metals on carcinogenicity and metabolism of nickel and cadmium. Biological Trace Element Research, No.13, (Aug 1987), pp. 253-273, ISSN: 0163-4984

Kapadia, G.J., Tokuda, H., Konoshima, T., Nishino, H. (1996). Chemoprevention of lung and skin cancer by Beta vulgaris (beet) root extract. Cancer Letters, Vol.100, No.1-2, (Febr 1996), pp. 211-214, ISSN: 0304-3835

Kong, A.N., Yu, R., Chen, C., Mandlekar, S., Primiano, T. (2000). Signal transduction events elicited by natural products: role of MAPK and caspase pathways in homeostatic response and induction of apoptosis. Archives Pharmacological Research, Vol.23, No.1, (Febr 2000), pp. 1-16, ISSN:0253-6269

Kovács-Nagy, E., Blázovics, A., Fébel, H., Szentmihályi, K., Sárdi, É. (2009). Chromatographic analytical opportunities on a thin film of mobilizable methylgroups of different biological objects under the influence of exogenic treatment. Acta Biologica Szegediensis, Vol.53, Suppl. 1, pp. 54. ISSN: 1588-385X

Kuramoto, Y., Yamada, K., Tsuruta, O,, Sugano, M. (1996). Effect of natural food colorings on immunoglobulin production in vitro by rat spleen lymphocytes. Bioscience Biotechnology and Biochemistry, Vol.60, No.10, (Oct 1996), pp. 1712-1713, ISSN: 09168451

Lever, M., Sizeland, P.C., Bason, L.M., Hayman, C.M., Chambers, S.T. (1994). Glycine betaine and proline betaine in human blood and urine. Biochim Biophys Acta, Vol. 1200, No.3, (Aug 1994), pp. 259-264, ISSN: 0304-4165

Lichszteld, K., Kruk, L. (1977). Singlet molecular oxygen in formaldehyde oxidation. Zeitschrift für Physicalische Chemie. (N F) Vol.108, pp. 167-172, ISBN: 0044-3336

Lugasi, A., Hóvári J. (2002). Flavonoid aglycons in food of plant origin II. Fresh and dried fruits. Acta Alimentaria, Vol. 31, No.1, (Feb 2002), pp. 63-71. ISSN: 0139-3006

Máday, E., Szentmihályi, K., Then, M., Szőke, É. 2000. Mineral element content of chamomile. Acta Alimentaria, Vol. 29, No.1, (Febr 2000), pp. 51-57, ISSN:0139-3006

Maehle, L., Metcalf, R.A., Ryberg, D., Bennett, W.P., Harris, C.C., Haugen, A. (1992). Altered p53 gene structure and expression in human epithelial cells after exposure to nickel. Cancer Research, Vol.52, No.1,(Jan 1992), pp. 218-221, ISSN: 0008-5472

Malaguarnera, L., Ferlito, L., Imbesi, R.M, Gulizia, G.S., Di Mauro, S., Maugeri, D., Malaguarnera, M., Messina, S.S. (2001). Immunosenescence: a review. Archives of Gerontology and Geriatritcs,. Vol. 32, No.1, (Febr 2001), pp. 1-4, ISSN: 0167-4943

Meyer, M., Schreck, R., Baeuerle, P.A. (1993), $\mathrm{H}_{2} \mathrm{O}_{2}$ and antioxidants have opposite effects on activation of NF-kappa B and AP-1 in intact cells: AP-1 as secondary antioxidantresponsive factor. EMBO Journal, Vol.12, No.5, (May 1993), pp. 2005-2015, ISSN: 0261-4189

Millan, N.S., Garrow, T.A. (1998). Human betaine-homocysteine methyltransferase is a zinc metalloenzyme. Archives of Biochemistry and Biophysics, Vol.356, No.1 (Aug 1998), pp. 93-98, ISSN: 0003-9861

Murakami, T., Magamura,Y., Hirano, K., (1998). The recovering effect of betaine on carbon tetrachloide indiced liver injury. Journal of Nutritional Science and Vitamology, (Tokyo), Vol.44, No.2, (Apr 1998), pp. 249-255, ISSN:0301-4800

Nieva, J., Wentworth, P.Jr. (2004). The antibody-catalyzed water oxidation pathway - a new chemical arm to immune defence? Trends in Biocheical Science, Vol.29, No.5, (May 2004), pp. 274-278, ISSN: 0968-0004 
Nyirády, P., Blázovics, A., Romics, I., May, Z., Székely, E., Bekő, G., 1 Szentmihályi, K. (2009a). Microelement concentration differences between patients with and without prostate adenocarcinoma. Vol. 3. Deficiency or excess of trace elements in the environment as a risk of health, Eds. Szilágyi M. and Szentmihályi K. Hungarian Academy of Sciences, pp. 26-30. TEFC. Budapest, ISBN:

Nyirády, P., Romics, I. (2009b). Textbook of Urology 2009. Semmelweis Kiadó és Multimédia Stúdió, ISBN: 9789639879232

Nyirády, P., Sárdi, É., Bekő, G., Szúcs, M., Horváth, A., Székely, E., Szentmihályi, K., Romics, I., Blázovics, A. (2010). Effect of bioactive molecules of Beta vulgaris L. ssp. Esculenta var. rubra on metastatic prostate cancer. Orvosi. Hetilap, Vol.151, No. 37, (Sept 2010), pp. 1495-1503, ISSN: 0030-6002

Pedreno, M.A., Escribano, J. (2000). Studying the oxidation and the antiradical activity of betalain from beet root. Journal of Biological Education, Vol.35, No.1, (Jan 2000), pp. 49-51, ISSN: 0021-9266

Pena, M.M., Lee, J., Thiele D.J. (1999). A delicate balance: homeostatic contol of copper uptake and distribution, Journal of Nutrition, Vol.129, No.7, (Jul 1999), pp. 12511260, ISSN: 0022-3166

Polya, G.M., Polya, Z., Kweifio-Okai, G. (2002). Biochemical pharmacology of antiinflammatory plant secondary metabolites. In Recent Progress in Medicinal Plants Vol.8, (Ed) E. Sighn, J.N. Govil, V.K. Sighn, SCI TECH Publishing, Houston, Texas, USA., pp. 1-22. ISBN: 1930813139

Powis, G., Gasdanska, J.R., Baker, A. (1997). Redox signaling and the control of cell growth and death. Advances in Pharmacology, Vol.38, pp. 329-358, ISSN: 0009-9236

Rice-Evans, C.A., Miller, N.J., Paganga, G. (1999). Antioxidant properties of phenolic compounds. Trends Plant Science. Vol.2, No.4, (April 1997), pp. 152-159, ISSN: 13601385

Rosenbaum, E., Hoque, M.O., Cohen, Y., Zahurak, M., Eisenberger, M.A., Epstein, J.I., Partin, A.W., Sidransky, D. (2005). Promoter hypermethylation as an independent prognostic factor for relapse in patients with prostate cancer following radical prostatectomy. Clinical Cancer Research, Vol.11, No.23, (Dec 2005), pp. 8321-8525, ISSN: 1078-0432

Salnikow, K., Zhitkovich, A. (2008). Genetic and epigenetic mechanisms in metal carcinogenesis and cocarcinogenesis: nickel, arsenic, and chromium, Chemical Research in Toxicology,. Vol.21, No.1, (Jan 2008), pp. 28-44, ISSN: 0893-228X

Sárdi, É., Stefanovits-Bányai, É., Kocsis, I., Takács-Hájos, M., Fébel, H., Blázovics, A. (2009). Effect of bioactive compounds of table beet cultivars on alimenary induced fatty livers of rats. Acta Alimimentaria, Vol.38, No.3, (Sept 2009), pp. 267-280, ISSN: 01393006

Sárdi, É., Tordai E. (2005). Determination of fully N-methylated compounds in different cabbage and beetroot varieties. Acta Biologica Szegediensis, Vol.49. No.1-2, pp. 43-45, ISSN: 1588-385X

Schroeder, J.J., Cousins, R.J. (1990). Interleukin 6 regulates metallothionein gene expression and zinc metabolism in hepatocyte monolayer cultures. Proceedings of the National Academic of Science U S A. Vol.87, No.8, (Apr 1990), pp. 3137-3141. ISSN: 0027-8424 
Schwartz, S.J., von Elbe, J.H., Pariza, M.W., Goldsworthy, T., Pitot, H.C. (1983). Inability of red beet betalain pigments to initiate or promote hepatocarcinogenesis. Food and Chemical Toxicology, Vol.21, No.5, pp. (Oct 1983), 531-535, ISSN: 0278-6915

Sigel, A., Sigel, H. (1999). Interactions between Free Radicals and Metal Ions in Life Processes. Metal Ions in Biological Systems, Marcel Dekker Inc., New York, Vol. No.36, pp. 1-797.

Skiba, W.E., Taylor, M.S., Wells, M.S., Mangum, J.H., Awad, W.M.J. (1982). Human hepatic methionine biosynthesis. Purification and characterization of betaine:homocysteine S/methyltransferase. Journal of Biological Chemistry, Vol.257, No.24, (Dec 1982). pp. 14944-14948, ISSN: 0021-9258

Slow, S., Lever, M., Lee, M.B., George, P.M., Chambers, S.T., (2004). Betaine analogues alter homocysteine metabolism in rats. The International Journal of Biochemistry and Cell Biology, Vol.36, No.5, (May 2004), pp. 870-880, ISSN: 1357-2725

Stead, L.M., Brosman, J.T., Brosman M.E., Vance D.E., Jacobs, R.L. (2006). Is it time to reevaluate methyl balance in humans? The American Journal of Clinical Nutrition, Vol.83, No.1, (Jan 2006), pp. 5-10. ISSN: 0002-9165

Stintzing, F.G., Carle, R. (2004). Functional properties of anthocyanins and betalains in plants food and in human nutrition. Trends Food Science and Techology, Vol.15, No.1, (Jan 2004), pp. 19-38, ISSN: 0924-2244

Stryeer, L. Biochemistry $3^{\text {rd }}$ (1988). ed. V.H. Freeman and Co., New York, ISBN: 0716719207

Suzuki, Y.J., Forman, H.J., Sevanian, A. (1997). Oxidants as stimulators of signal transduction. Free Radical Biology and Medicine, Vol.22, No.1-2, pp. 269-285, ISSN: 0891-5849

Szentmihályi, K., Blázovics, A., Lugasi, A., Kéry, Á., Lakatos, B., Vinkler, P. (2000a). Effect of natural polyphenol-type antioxidants (Sempervivum tectorum and Raphanus sativus L. var. niger extracts) on metal ion concentrations in rat bile fluid. Current Topics Biophysics, Vol. No.24, pp. 203-07, ISSN:

Szentmihályi, K., Csiktusnádi-Kiss, G.A., Keszler, Á., Kótai L., Candeaias, M., Bronze, M.R., Boas, L.V., Spauger, I., Forgács, E. (2000b). Method development for measurement of elements in Hungarian red wines by inductively coupled plasma optical emission spectrmetry (ICP-OES). Acta Alimentary, Vol,29, pp. 105-121, ISSN: 01393006

Szilvás, Á., Blázovics, A., Székely, Gy., Fehér, J. (1999). Free radical status and tumor markers in gastrointestinal tumors, European Congress, I.H.P.B.A. Budapest, (Ed) L. Flautner, P.K. Kupcsulik, I. Rózsa, Monduzzi Editore. International Proceeding Divison, pp. 409-412, ISSN: 2039-4632

Takács-Hájos, M. (1999). Color components of different table beet root varieties. International Journal of Horticulture Science, Vol. 5, pp. 3-4, ISSN: 1585-04040

Váli, L., Stefanovits-Bányai, E., Szentmihályi, K., Fébel, H., Sárdi, E., Lugasi, A., Kocsis, I., Blázovics, A. (2007). Liver-protecting effects of table beet (Beta vulgaris var. rubra) during ischemia-reperfusion. Nutrition, Vol.23, No2, (Feb 2007), pp. 172-178, ISSN: 0899-9007

Wang, M., Goldman, I.L. (1996). Phenotypic variation free folic acid content among F1 hybrids and open-pollinated cultivars of red beet. Journal of the Amarican Society for Horticultural Science. Vol.121, No.6, (Nov 1996), pp. 1040-1042, ISSN: 0003-1062 
Vanherweghem, J.L., Depierreux, M., Tielemans, C., Abramowicz, D., Dratwa, M., Jadoul, M, Richard, C., Vandervelde, D., Verbeelen, D., Vanhaelen-Fastre, R, et al. (1993). Rapidly progressive interstitial renal fibrosis in young women: association with slimming regimen including Chinese herbs. Lancet, Vol.13, No.341, (Feb 1993), pp. 387-391, ISSN: 0140-6736

Watson, R.E., Curtin, G.M., Doolittle, D.J., Goodman, J.I. (2003). Progressive alterations in global and GC rich DNA methylation during tumorigenesis, Toxicological Sciences, Vol.75, No.2, (Oct 2003), pp. 289-299, ISSN: 1096-6080

Wettasinghe, M., Bolling, B., Plhak, L., Xiao, H., Parkin, K. (2002). Phase II enzyme-inducing and antioxidant activities of beetroot (Beta vulgaris L.) extracts from phenotypes of different pigmentation. Journal of Agricultural and Food Chemistry, Vol.50, No.23, (Nov 2002), pp. 6704-6707, ISSN: 0021-8561

Wilchen, B., Dudman, N., Tyrrell, P.A. (1983). Homocystinuria-the effects of betaine. New England Journal of Medicine, Vol. 309, No.8, (Aug 1983), pp. 448-453, ISSN: 0028-4793

Wild, L., Flanagan, J.M. (2010). Genome-wide hypomethylation in cancer may be a passive consequence of transformation. Biochimica et Biophysica Acta, Vol.1806, No.1, (Aug 2010), pp. 50-57, ISSN: 0304-419X

Yuregir, G.T., Kayrin, L., Curuk, M.A., Acarturk, E., Unlukurt, I. (1994/1995). Correlation between trace elements and lipid profiles. Journal of Trace Elements in Experimental Medicine, Vol.7, pp. 113-118, ISSN: 0896-548X

Zakharova, N.S., Petrova, T.A. (1998). Relationship between the structure and antioxidant activity of various betalains. Prikladnaya Biocimimija i Mikrobiologiya, Vol.34, No.2, (March April 1998), pp. 199-202, ISSN: 0555-1099 


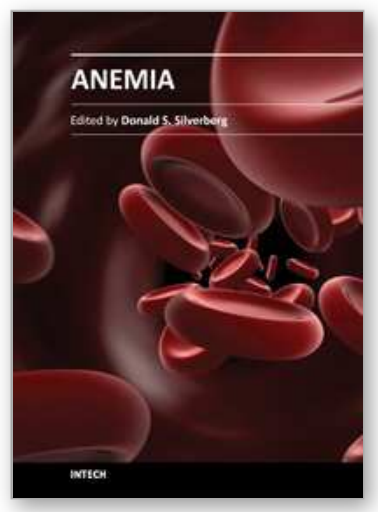

\author{
Anemia \\ Edited by Dr. Donald Silverberg
}

ISBN 978-953-51-0138-3

Hard cover, 440 pages

Publisher InTech

Published online 29, February, 2012

Published in print edition February, 2012

This book provides an up- to- date summary of many advances in our understanding of anemia, including its causes and pathogenesis, methods of diagnosis, and the morbidity and mortality associated with it. Special attention is paid to the anemia of chronic disease. Nutritional causes of anemia, especially in developing countries, are discussed. Also presented are anemias related to pregnancy, the fetus and the newborn infant. Two common infections that cause anemia in developing countries, malaria and trypanosomiasis are discussed. The genetic diseases sickle cell disease and thalassemia are reviewed as are Paroxysmal Nocturnal Hemoglobinuria, Fanconi anemia and some anemias caused by toxins. Thus this book provides a wide coverage of anemia which should be useful to those involved in many fields of anemia from basic researchers to epidemiologists to clinical practitioners.

\title{
How to reference
}

In order to correctly reference this scholarly work, feel free to copy and paste the following:

Anna Blázovics, Péter Nyirády, Imre Romics, Miklós Szűcs, András Horváth, Ágnes Szilvás, Edit Székely, Klára Szentmihályi, Gabriella Bekő and Éva Sárdi (2012). How Can Cancer-Associated Anemia Be Moderated with Nutritional Factors and How Do Beta Vulgaris L. Ssp. Esculenta Var. Rubra Modify the Transmethylation Reaction in Erythrocytes in Cancerous Patients?, Anemia, Dr. Donald Silverberg (Ed.), ISBN: 978-953-510138-3, InTech, Available from: http://www.intechopen.com/books/anemia/how-can-cancer-associatedanemia-be-moderated-with-nutritional-factors-and-how-do-beta-vulgaris-l-ss

\section{INTECH}

open science | open minds

\section{InTech Europe}

University Campus STeP Ri

Slavka Krautzeka 83/A

51000 Rijeka, Croatia

Phone: +385 (51) 770447

Fax: +385 (51) 686166

www.intechopen.com

\section{InTech China}

Unit 405, Office Block, Hotel Equatorial Shanghai

No.65, Yan An Road (West), Shanghai, 200040, China

中国上海市延安西路65号上海国际贵都大饭店办公楼405单元

Phone: +86-21-62489820

Fax: $+86-21-62489821$ 
(C) 2012 The Author(s). Licensee IntechOpen. This is an open access article distributed under the terms of the Creative Commons Attribution 3.0 License, which permits unrestricted use, distribution, and reproduction in any medium, provided the original work is properly cited. 